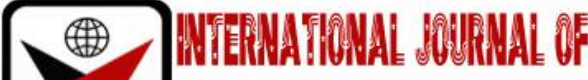

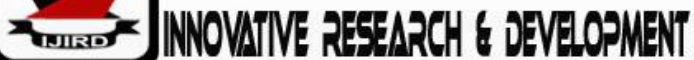

ISSN 2278-0211 (Online)

\section{Urban Sprawl and the Implications on Land Cover Change in Bafoussam, Cameroon}

\author{
Clement Anguh Nkwemoh \\ Associate Professor, Department of Geography, FALSS, \\ University of Yaounde, Cameroon
}

\begin{abstract}
:
Spotted at the core of the Western Highlands clothed by herbaceous, shrubby and tree savanna, the Bafoussam Metroplis epitomizes urban areas with socio-economic and ecological dynamics emanating from urban expansion. Loss of Vegetation and/or ecological disturbances accounts for the most remarkable impacts on spatial Land Cover dynamics in general. As such, mapping the affected area becomes indispensable in order to evaluate the magnitude of the effects to preempt sustainable development.

Topographic maps, Aerial photographs and Satellite images have been used in this research. The use of these different methods has facilitated comparisons. Other information was canvassed through interviews; meanwhile, the Internet has equally been instrumental in this research. Findings indicate that there has been an astronomical expansion of the urban space as a result of population explosion in Bafoussam. The rising number of mouths must be fed while equally being sheltered. Meanwhile all of these have imposed increased need for farm land and building space. The resulting Land Cover shows a predominance of vegetation before 1978, a continuous drop in 1998and a great loss of land occupied by vegetation in 2018. REDD+ has been proposed as one of the alternative measures to revamp the situation and this entails sustainable management practices. It is an approach that would guarantee an ecological/Bio city that Bafoussam is supposed to be.
\end{abstract}

Keywords: Population growth, urban expansion, remote sensing, geographic information system, vegetal degradation, land cover change

\section{Introduction}

Any natural habitat that is exposed to either internal or exogenous forcings/influences is bound to witness some internal dynamism as a compensation of the impacts. What might differ is the degree of change as a result of the modification emanating from the various forcings. Most if not all urban spaces are a true testimony of agglomerations where rapid population increase has imposed the need of more space forthe construction of homes for the population.In addition to the increase in population number, the society is bound to push to open more land for agriculture so as to meet up with the more mouths to feed. The situation has made most of the city dwellers to occupy the nooks and crannies of the area not only for the construction of houses but also space for agriculture.

Urban expansion is a common phenomenon in most of the agglomerations in Cameroon in particular and the subSaharan Africa as a whole (Gleave, 1992a, 1992b and 2001; Fombe \& Balgah, 2010 and Nkwemoh, 2011). The issues on man induced forces and the implication on landscape have been viewed by Harding (1968); Martin (1985); Bopda (1985); Goudie (1986); Brinkman (1990), Nkwemoh (2011) and Nkwemoh et al (2017). Other works related to our theme are more oriented towards treatment of satellite images such those of Assako (1998), Moshen (1999), Pratt (1991) Akono (1994), Tonye et al (2000), Begue et al (2010). Meanwhile other related works focus on the treatment of images and land cover change such as those of Turner et al (1995), Jukka \& Aristide (1998), Neba Shu (2003) Ngouanet (2007); Nkwemoh (2011), Lambi and Kah (2012), Nkwemoh and Lambi (2016), Nkwemoh and Yungsi Nkwemoh (2019)

According to the FAO 42.1\% (19.1916000 hectares) of Cameroon is forested; although other estimates hold that forest cover is up to 4\%. Between 1990 and 2010, Cameroon lost an average of 220,000 hectares of forest (0.9\%) per year (MINFOF, 2015). In total, between 1990 and 2010 Cameroon lost 18.1\% (4,400,000hectares) This is because of a number of factors that include; mass forest exploitation; urbanization; developmental project (such as the construction of dams, the construction of sea ports and the setting up of plantations such as the CDC, SGSOC and many others. These are considered as major threats to the forest sector of the country because for this to go on well, large expanses of forest land must destroyed.

The goal of this is paper is to investigate on how the sprawl of the Bafoussam urban space has imposed the search for more space by Urban dweller. It also deals with the effects of rapid and uncontrolled urban expansion/sprawl on vegetation and/or land cover dynamics. The article has been structured into parts that fall under the biophysical background, materials and methods, results and discussions as well as conclusion 


\section{Bio-physical Background}

Bafoussam town (Figure 2) is found at $X=657272,5$ being Longitude $10,4197^{\circ}$ East of the Greenwich Meridian and $Y=604971,6$ being Latitude $05,4715^{\circ}$ North of the Equator. This absolute location has been deduced with the GPS at the Roundabout at Hotel de Ville. Bafoussam is the headquarter of the West Region of Cameroon. The town is found on part of the High Plateau at an altitude that varies between $1000-1600 \mathrm{~m}$ above Sea level. A view of the topographic assemblage permits a classification into 3 different relief units. They are; the section with an altitudinal range from 900 $1100 \mathrm{~m}$ with the section that bears the Rivers Mifi and Noun. It is the part that merges with the Noun plaine and bordered by the high relief of the town. The next is the intermediate level with altitudes from $1100-1300 \mathrm{~m}$ constituting the main seat or the core of the town towards the north. On this first stage water courses have incised narrow valleys. The hillslopes with slope gradients increase from the summits to the base and are equally convex. Meanwhile towards the northern part of this sector, the slopes become gentle. The last level of $1400-1500 \mathrm{~m}$ and above occupies the southern half and it has a SW inclination. The relief is equally varied; with deep valleys carrying steams and their tributaries.

Concerning the hodrology, a result of the configuration of the relief, the water courses are divided into three main catchments whose watersheds are occupied by main roads. The first one occupies the right bank of the river Metchie beyond the Baleng hills. The second catchment occupies the Western and South West drained by two tributaries of the Metchie flowing from East to West from the heart of the town to North West. The third one occupies the Eastern sector. It is formed by the right bank of the River Noun that has a North/South direction of flow

The Bafoussam town belongs to the structural assemblage of the Bamileke Plateau characterized by parent materials that had been metamorphosed and granitized just as its evolution portray an evolution of the geomorphical trait that has become more complex. Since the Precambrian period, the relief that was laid down during successive orogenesis were exposed to denudational forces that wore down their surface. After this, the different tectonic phases and those of the secondary and tertiary era that followed, controlled the processes towards the basement complex. The present geomorphology is greatly controlled by two successive evolutions. The first is the process that entails activities of diastrophism that characterized the tertiary era.

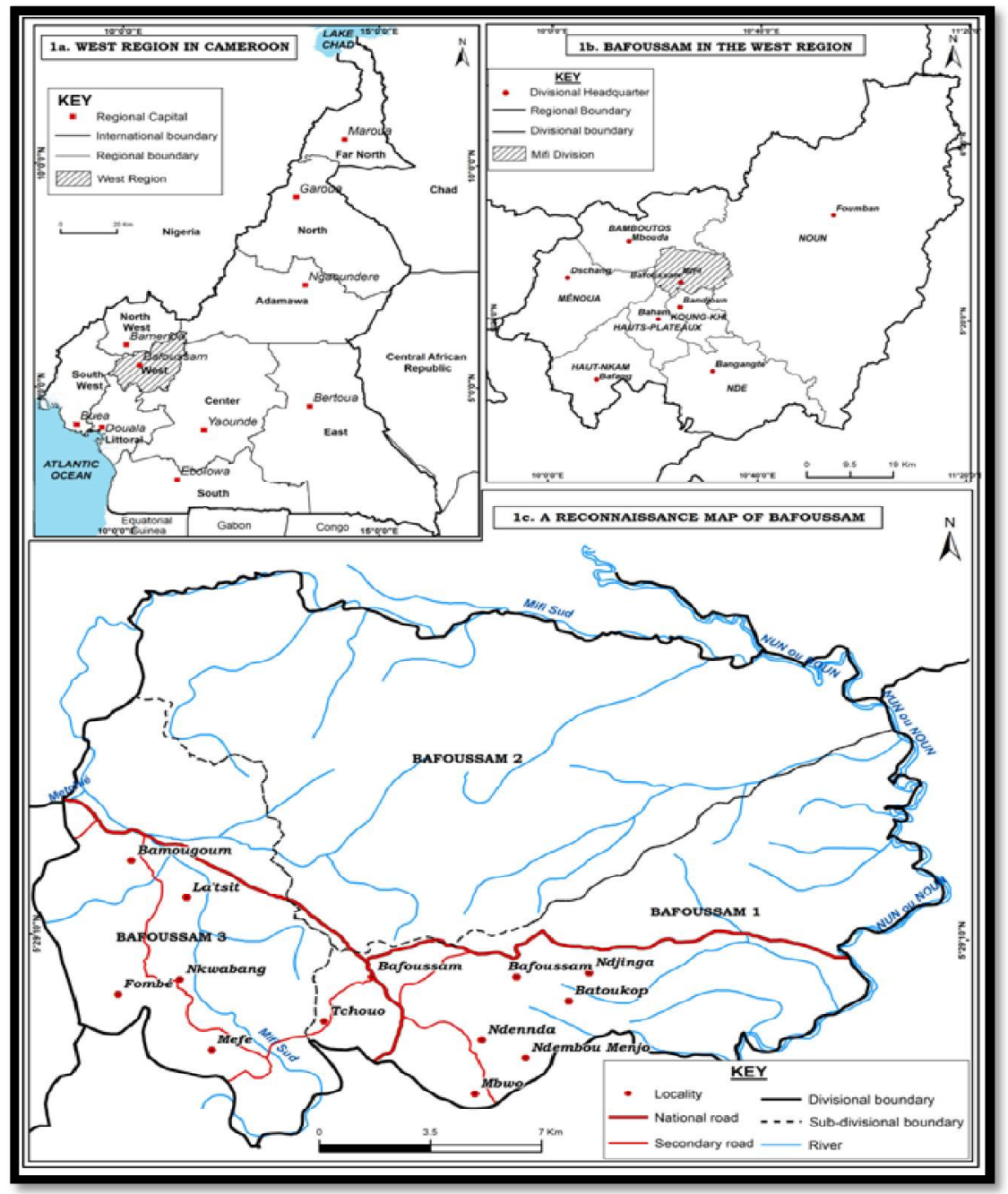

Figure 2: Location of the Study Area

The minor seimes noticed today are signs of ancient movements that have deformed the basement complex, causing the readjustment of blocks from time to time. The movements around this area are strictly linked to the tectonic activities of the Great Cameroon Line. The second evolution comprises volcanic eruption mainly composed of basaltic flows of the Mount Bamboutos System that probably took place in Miocene (16M - 5.3M years) that overwhelmed the 
raised and faulted basement complex. This filling stage has contributed to the coverage of the old structural directions that are only perceptible today through some isolated horsts. Serious erosion has also greatly sculptured the relief of this site of Bafoussam town that has no doubt had a very active geological history.

The climate of Bafoussam falls within the zone that has two marked seasons, controlled by the monsoon from the Gulf of Guinea from the South West and the Harmattan or North East Trade Winds from the Saharan Region in the Northern part of Cameroon. The dry season runs from November to March meanwhile the rainy season runs from April to October. The rainfall is relatively abundant with an average of $1800 \mathrm{~mm}$ per year and precipitated at an average of $110-$ 130 days per year. July, August and September are the freshest periods of the Year. The annual average temperature is about $20^{\circ} \mathrm{C}$ hovering between $18^{\circ} \mathrm{C} \& 23^{\circ} \mathrm{C}$ with absolute maxima of $21^{\circ} 7 \mathrm{C}$ in March and absolute minima around $9^{\circ} 5 \mathrm{C}$ in July.

Bafoussam town is part of the grassfields that is predominated by Savanna. The vegetation is basically herbaceous savanna with Pénnisetum Purperum \& Impérata Cylindrica. Most of the valleys are to be found with gallery forests composed of raffia bushes. There are also planted forest that are basically composed of fruit trees such as pear trees Mango trees, Plums, Guava etc. as well as ornamental and shade trees such as Eucalyptus, Cypress and Whistling pines. Most importantly there are sacred forests in the area to be spotted mainly around three chiefdoms (Palaces) which are found in Bafoussam 1, 2 \& 3.

With regards to the soil of Bafoussam, there are three sub types. The first type is the brown soil on basaltic rock. It possesses many classes that include Alfisols, Inceptisols-Lixisols Luvisols. These are richer than their counterparts-the red soils in in Baleng, Bapi, Bamoungoum, Bansoa, Baleveng and Balessing. These soils possess high organic content and their chemical properties are balanced and therefore they are very fertile soils. The second type of soil is the young soil made of Lithosols derived from basalt. These soils range generally from Intisols or Inceptisols that have been highly used and impoverished by the high population density. The third type, entails the black soil on volcanic ash/cinder. The soil is very rich except for its deficiency in oligo-elements (copper and zinc). The soil is mostly found around Bapi and baleng. Most of the humid valleys occupied by raphia carry sediments that have been eroded and deposited to produce hydromorphic soils that are dark and less aerated are equally very fertile for Market gardening.

According to his majesty Njitack Ngompe Pelé, Edition COGNITO (September 2008), Under the pressure of Peul invaders who were invading to Islamise the region towards the $17^{\text {th }}$ Century; the Bafoussam natives had many migratory waves moving from the Kassap to Fankou and then to Houa in Bandjoun, Katchuet and Fancep. It was after many decades of migrations that the Chief decided to settle at the site of "Ngoungfoussem" - The Kingdom of Bafoussam at "Hiala", its present site. Originally, Bafoussam is in bafoussam dialect - "Pefussep" which literally signifies "those from ......" with time, "Pe" was transformed into "Ba" why maintaining the same meaning. Meanwhile "foussan" became foussam and together with the above, the produced 'Pefuhssap' or 'Pefuhssep' meaning Bafoussam. Pefuhssap or Pefuhssep simply means "Those who have discovered the profit or treasure are found in the retail trade. Bafoussam is a tribal group that is composed of 07 villages. (Bamendzi, Banengo, Ndiangdam, Ndiangsouoh, Ndiangbou, Toukouop, Ngoueng, et Banengo ville B) with 41 quarters

\section{Research Methodology}

Various institutions have been consulted for data collection, including the University of Yaoundé I, the World Bank, the Ministries of Environment, Nature Protection and Sustainable Development and the Bafoussam Urban Council. In order to establish comprehensive satellite images to determine land cover and land use, information was gotten from LANDSAT. We proceeded with access to the GLCF (Global Land Cover Facility) and then the ESDI (Earth Science Data Interface). With the study of images from MSS (Multi Spectral Scanner or Generation 1 satellite) and TM (Thematic Mapper or Generation 5 satellite) and ETM+ (Generation 7 Satellite) as well as Google Earth, we proceeded with a workable procedure which entailed the determination of the Path and Row. Earth explorer and Google Earth we utilized for ground truthing/verification. Using the ETM+ (Enhanced Thematic Mapper + ) the Scene that carries Bafoussam could be traced following Path 186 and Row 056 between the period 1978, 1998 and 2018(Figure 1).

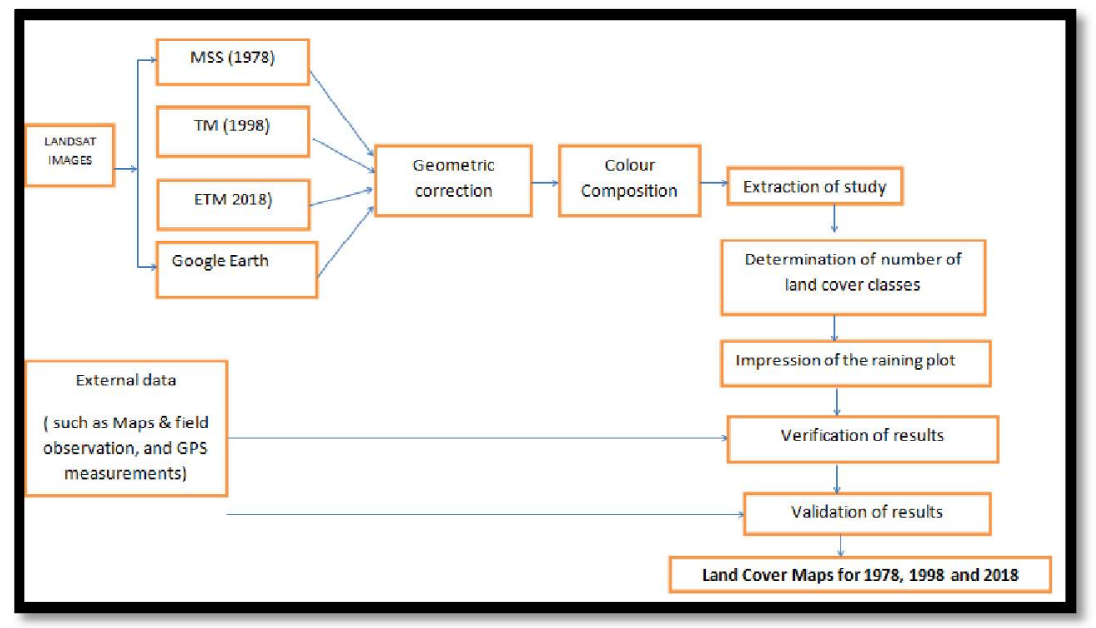

Figure 1: Methodological Approach for the Treatment of Satellite Images 
Given that each Scene has a surface area of $185 \mathrm{~km}^{2}$ and that the scene is composed of many pixels with each pixel having a surface area of $30 \mathrm{~m}$, various bands were determined in order to exploit and show the various aspects that constitute the land cover classes. ASTER Images also assisted in the elaboration of Digital Elevation Model (DEM) and the Hydrology

The ERDAS software program was then utilized in the location and combination of the various colour bands. Then the bands appear with the possibility of RGB colour instead of gray scales. With, the Supervised and on Signature Editor, then zooming of the image, the sample by polygons of each form of feature was taken and attributed a colour. For instance green for vegetation, brown for bare surfaces and blue (or water surfaces) constituting Land Cover Classes (LCC). The ArcGIS program in combination with the above software was subsequently used in delimiting various land cover classes. The technique has been utilized with success by Assako (1998), Bauer \& als (2003); Pratt (1991), Tonye \& als (2000) and Nkwemoh (2017). Global Position System (GPS) was equally utilized for collection of points.

Land Cover Classification was done by the use of the following formula $\frac{L C C 1}{T L C} \times \frac{100}{1}=\%$ LCC 1 of TLC

LCC1b-LCC1a = Rateof change for LCC1 for 1978 - 1998 (20years)

Where LCC $=$ Land Cover Class

TLC $=$ Total Land Cover

LCC1a = Land Cover Class for Built - up area for the year 1978

LCC1b = Land Cover Class for Built -up area for the year 1998

LCC1c = Land Cover Class for Built - up area for the year 2018

We collected numerical Census data (1950, 1976, 1987 and 2005) and estimate projection of population of Bafoussam in that we computed using Microsoft EXCEL. The GIS programs such as Adobe Illustrator 9.0 and ArcGIS 10.2 softwares have been used for cartography. Population projection was done by the use of the formula;

$$
\mathrm{P}_{\mathrm{x}}=\mathrm{P}_{2}+\mathrm{N} / \mathrm{n}\left(\mathrm{P}_{2} \cdot \mathrm{P}_{1}\right)
$$

Where $\mathrm{P}_{\mathrm{x}}=$ Projected Population

$$
\begin{aligned}
& \mathrm{P}_{1}=\text { Initial Population } \\
& \mathrm{P}_{2}=\text { Last known Population } \\
& \mathrm{N}=\text { Period between } \mathrm{P}_{1} \& \mathrm{P}_{\mathrm{x}} \\
& \mathrm{n}=\text { Period between } \mathrm{P}_{1} \& \mathrm{P}_{2}
\end{aligned}
$$

\section{Results and Discussions}

\subsection{Rapid population increase and Urban Expansion}

Bafoussam was created in 1925 as an administrative post and grew up moderately till 1958 with the outbreak of the socio-political crisis that witnessed an influx of population from the rural areas in search of security. The population then increased from 10.000 inhabitants in 1958 to 60.000 in 1976 and then 231.000 in 2005.Applying the growth rate of the population observed in 1987 and 2005, the population of Bafoussam can be estimated in January 2010 to be 282800 (table 1 and Figure 3). With this population, the weight of the total urban population of the whole Region is $13.9 \%$. This relatively low weight is explained by the high number of agglomerations that are found along the National Highway(N5 and N6)

The pull factors of the population centre around the fact that Bafoussam is a roundabout town that is located at the pinnacle of inter-regional exchange. Secondly, it is the Administrative Headquarter or Capital that attracts service sectors. Thirdly its position permits it to enlarge regional influence on the North West and Adamawa Regions. It has a significant might/weight that comes from its prolonged demographic trends.

\begin{tabular}{|c|c|c|c|c|c|}
\hline Year & $\mathbf{1 9 7 6}$ & $\mathbf{1 9 8 7}$ & $\mathbf{2 0 0 5}$ & $\mathbf{2 0 1 0}$ & $\mathbf{2 0 1 8}$ \\
\hline Population & 62239 & 112681 & 239287 & 282800 & $321962^{* *}$ \\
\hline Growth Rate & & 5,5 & 4,1 & 4,1 & \\
\hline
\end{tabular}

Table 1: The Evolution of Population of Bafoussam

**Projections

Source: BUCREP (2005) Bafoussam Urban Council (2017) and Projections 


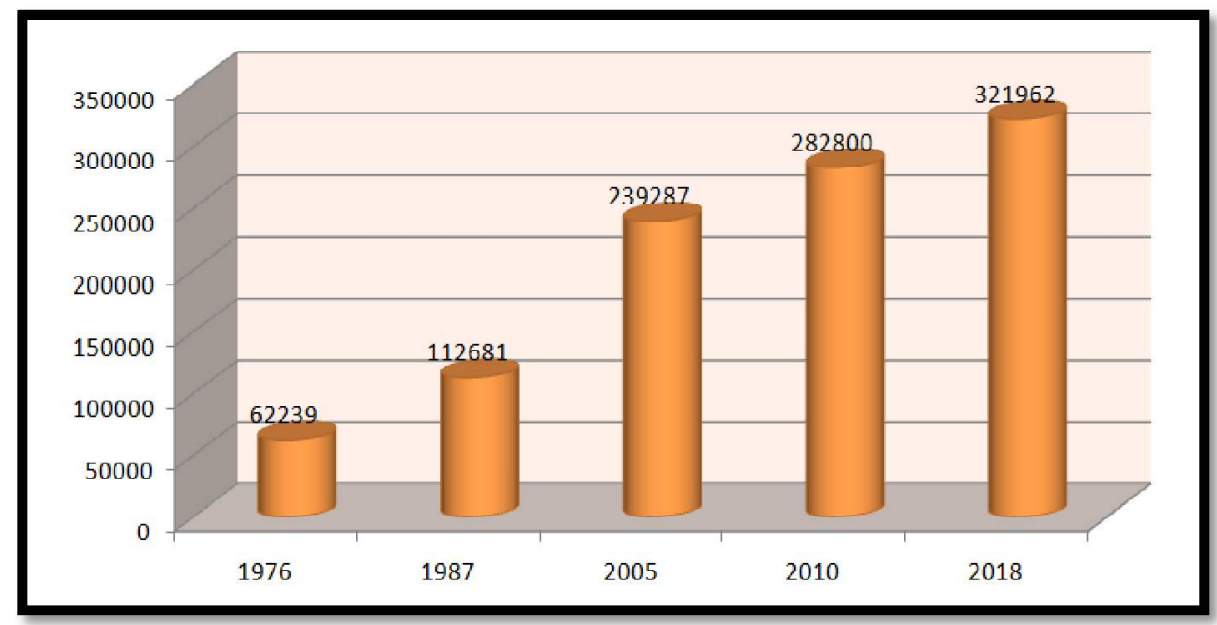

Figure 3: The Evolution of Population of Bafoussam

Source: BUCREP (2005)Bafoussam Urban Council (2017) And Projections

Considering the Mifi Division, that covers the whole of the Urban Council, the total number of population was estimated at 301456 inhabitants in 2005. The urban population stood at 239287 being $79 \%$ of the total while the Rural population was 62169 persons (Table 2)

\begin{tabular}{|c|c|c|c|}
\hline Council & Urbaine & Rurale & Total \\
\hline Bafoussam & 81611 & 16728 & 98.339 \\
\hline Baleng & 99524 & 21758 & 121282 \\
\hline Bamougoum & 58152 & 23683 & 81835 \\
\hline City Council & 239287 & 62169 & 301456 \\
\hline
\end{tabular}

Table 2: Population by Place of Residence

Source: Bafoussam Urban Council (2017)

The population of Bafoussam has mutated over the past years till today that it has become the primate city in the Western region followed by smaller towns like Mbouda, Dschang, Bafang and Foumban amongst others.

The term city has no unique definition sine it varies with space and time.but is not uncommon to be associated the meaning of the term with demographic characteristics. The United Nation holds that all places with more than 20.000 inhabitants living together are urban. However, some Nations compile their statistics on the basis of different standards. The United States for example considers an 'urban space' as and area where more than 2500 people live. Irrespective of numerical definition, it is evident that the later course of human history after the Industrial revolution has been marked by a process of Urbanization.

Figure 4 shows the degree and evolution of spatial coverage of built-up area that constitutes that arena of townscape. The function of the urban space is a true testimony of an artificial ecosystem that is replacing a natural system.

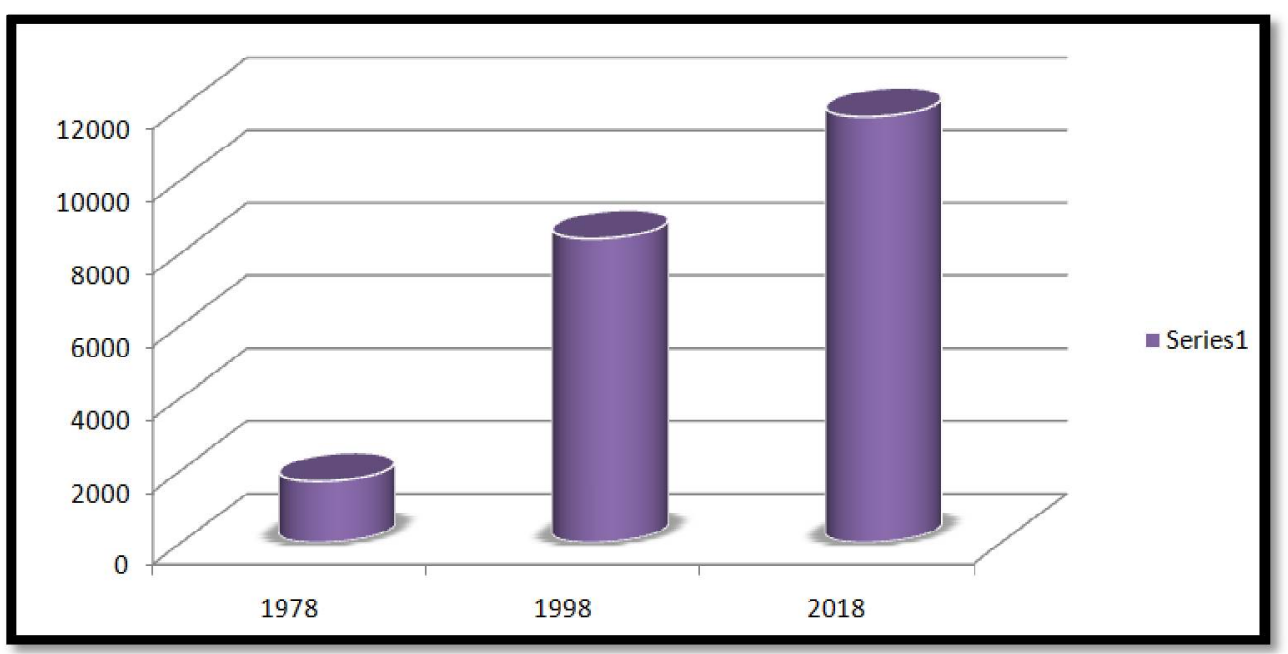

Figure 4: The Evolution of Urban Expansion in Bafoussam

Source: Satellite Images for Bafoussam 1978, 1998 \& 2018

Normally in the natural ecosystem, there is an array of species that live together, playing different roles and interacting with one another as well as their natural habitat. In an urban ecosystem, man is the principal actor and even if there are other members of the ecosystem, their roles are either insignificant or non-existent. In the townscape therefore, 
there comes the confrontation of Landuse imposed by Man and land cover that entails both what is laid down by Nature and by Man. Findings from the field show that about 70\% of the houses in Bafoussam are owned by individuals and about 80 to $90 \%$ of those who occupy the house according to the Urbanization Master Plan (PDU) of Bafoussam (2018) are the Proprietors/Owners. The same source holds that the number of Tenants is very insignificant

\subsection{Impact on Land Cover Dynamics}

Results from field inquiries and analyses of satellite images give an impressive picture of the land cover dynamics of the Town (Table 3)

\begin{tabular}{|c|c|c|c|c|c|c|}
\hline \multirow{2}{*}{ Landcover } & \multicolumn{5}{|c|}{ Surface Area In Hectares And Percentage } \\
\cline { 2 - 7 } & \multicolumn{2}{|c|}{$\mathbf{1 9 7 8}$} & \multicolumn{2}{c|}{$\mathbf{1 9 9 8}$} & \multicolumn{2}{c|}{$\mathbf{2 0 1 8}$} \\
\hline & Hectares & $\mathbf{\%}$ & Hectares & $\mathbf{\%}$ & Hectares & \% \\
\hline Forest & 7157 & 17.4 & 2779 & 7 & 2281 & 6 \\
\hline Savanna & 24992 & 60.9 & 19725 & 47.5 & 14805 & 36 \\
\hline Built-up area & 1692 & 4 & 8383 & 20 & 11748 & 28 \\
\hline Hydrography & 294 & 0.7 & 138 & 0.3 & 101 & 0.2 \\
\hline Cultivated land & 7101 & 17 & 10211 & 25 & 12301 & 29.8 \\
\hline Total & 41236 & 100 & 41236 & 100 & 41236 & 100 \\
\hline
\end{tabular}

Table 3and Figures 5, 6 \& 7 show the spatio-temporal evolution of landcover over the past 4 decades. The primary vegetation of forest has regressed progressively. The thinning down in the surface of the areas by these land use systems are evident. Firstly, there is an increase in the built-up area from 1692 in 1978 being 4\% of the total area to 8383 in 1998 being $20 \%$ of the total surface area to 11748 accounting for $28 \%$ of the total surface area.

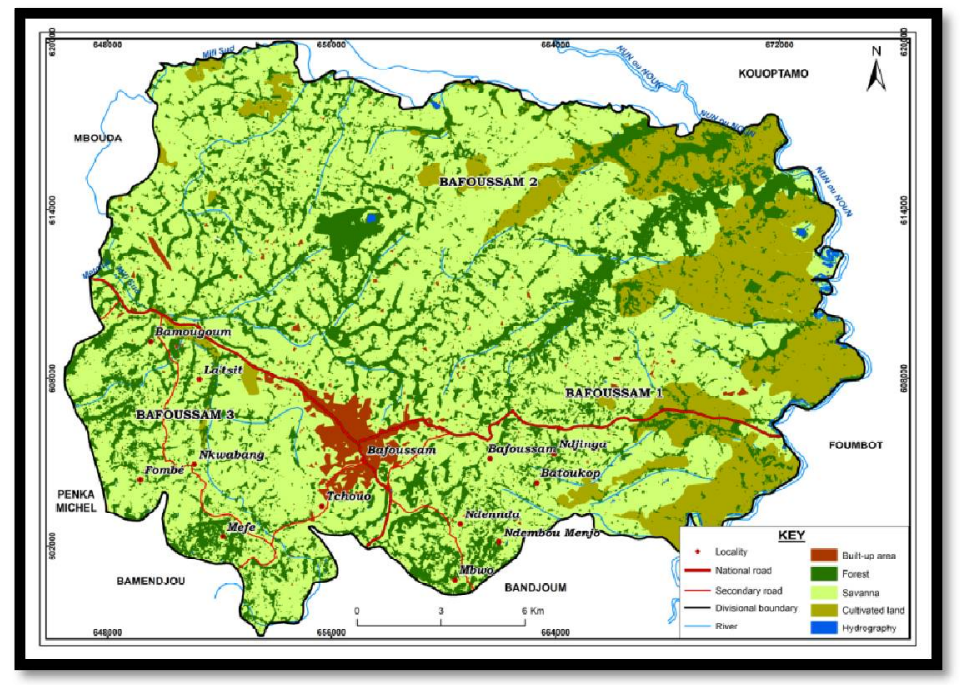

Figure 5: Land Cover in 1978

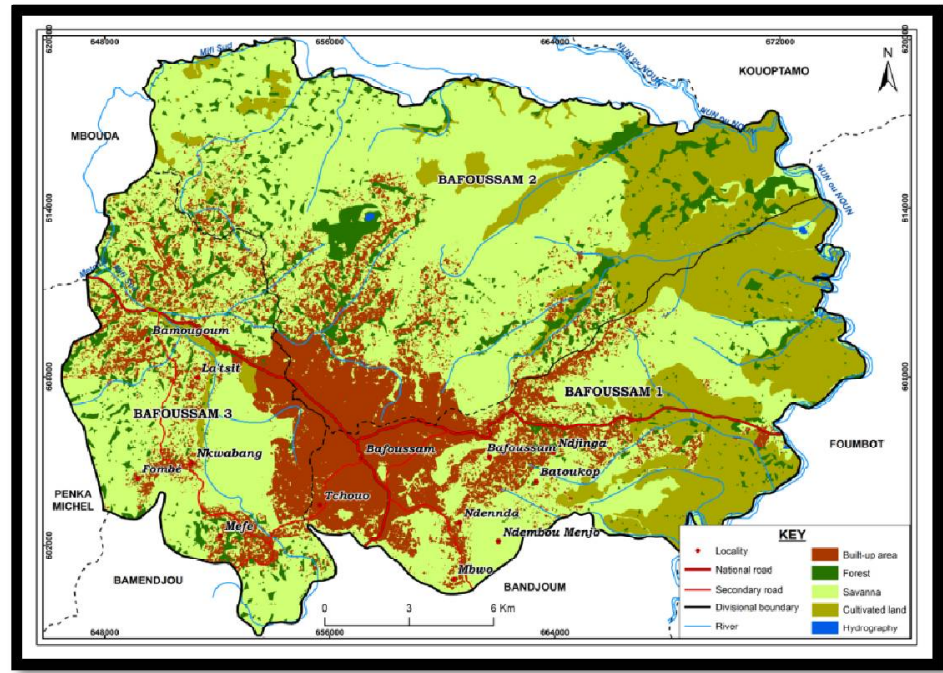

Figure 6: Land Cover in 1998 


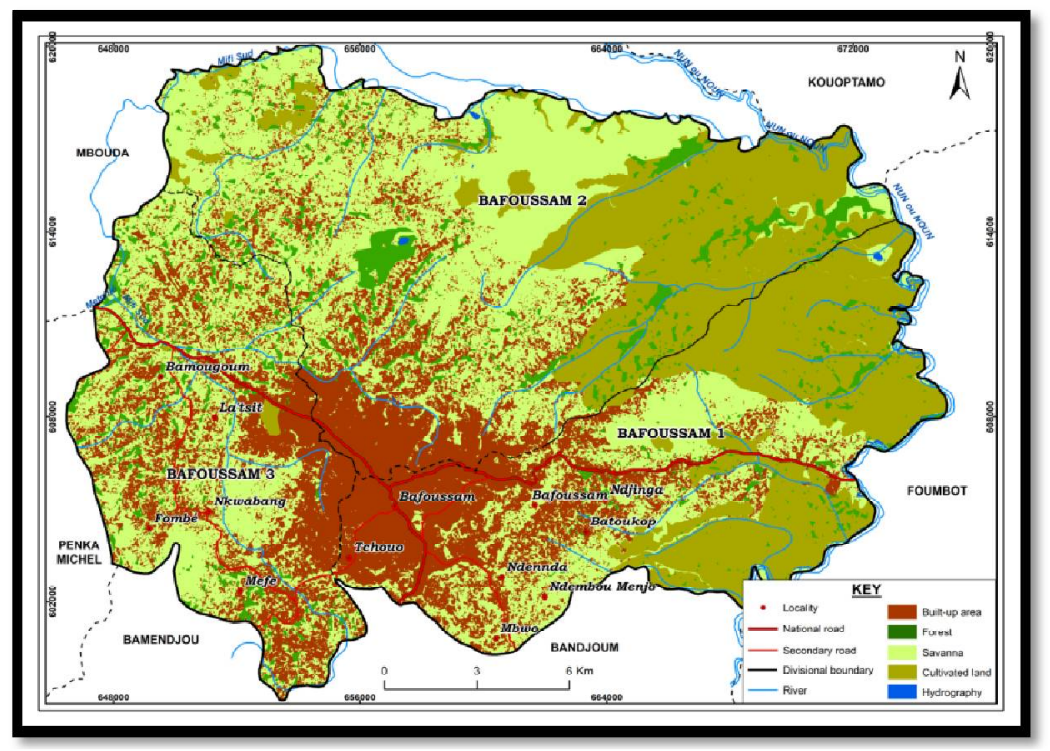

Figure 7: Land Cover for 2018

This presupposes the space taken from forest, savanna and wetlands for house holdings.

Secondly, the Land cover represented by cultivated/farmland, fallows and bare surfaces have increased steadily from 7101 being $17 \%$ of the total surface area in 1978 to 10211 being $25 \%$ of the total surface area in in 1998 through to 12301 being $29.8 \%$ in 2018 . There has been evidently and encroachment onto the forest by the population for subsistence farming and market Gardening. This only gone a long way to increase pressure on a vegetation that is already suffering from the pressure of rampant house constructions.

Thirdly, Forest cover has strongly witnessed a shrinkage from 7157 being 17.4 of the total surface areas in 1978 to 2779 being $7 \%$ of the total surface area in 1998 to 2281 being $6 \%$ of the total surface area in 2018. According to findings on the field, this reduction can be attributed to a number of forcings. The construction of houses by both traditional and conventional methods needs forest products especially in the building and roofing processes. This impact on forest vegetation has been exacerbated by the need of Fuel wood/Charcoal for domestic purposes. The degradation of forest cover has even been aggravated the need of a wide variety of wood for woodworks/furniture especially needed in the increasing number of households.

Fourthly, Derived grassland or Savanna cover has decreased from 24992 being, 60.9\% in 1978 to 19725, being $47.5 \%$ of the total surface area in 1998 through to 14805 , being $36 \%$ of the total surface area in 2018. Since the landscape is basically of herbaceous and shrubby/tree savanna urban expansion increase in housing need and farmland expansion are the root cause of the vegetal and hence land deterioration.

Finally water bodies and wetlands have equally witnessed a drop in their surface area from 294 , being $0.7 \%$ in 1978 to 138 , being 0.3 in 1998 , through to 101 , being $0.2 \%$ in 2018 . These drops are proven to be the results of the impact of the main stressors embodied in expansion around the urban space and other land uses. Foundat the roundabout of the National Highways 6 and 4, the urbanized zone appears to develop in a concentric manner around this growth. The difficulties imposed by the relief forces the town to spread along the main Highways to the point where a conurbation is being attained where the city merges with Bandjoun

\section{Recommendation}

The Land Occupation Plan (POS), the Master Plan of Urban Development PDU and/or PSU of the Bafoussam Urban Council had been greatly exploited to view the part touching sustainable management of the milieu. The BafoussamUrban Council has been working in collaboration with the Divisional Delegation of Housing and town planning and the Ministry of Forest and Fauna to create and maintain lawns and green areas within the Bafoussam city. These are measures that are taken to safeguard the environment. It is worthwhile noting that, more needs to be done to ameliorate theecology and guarantee a bright future for the natural environment.

\subsection{Town Planning and Housing Strategy}

Another way that the government can solve the problem of anarchical growth concerns what is partially being practiced. This is by funding and ensuring the construction of multiple housing structures. The type of housing structure recommended here includes, single and double room complexes. This is because city dwellers are composed of basically the youthful and middle age population. The buildings should be in blocks of about 6 storeys. This option is more efficient with vertical constructions. As such, the use of 4 hectares $\left(40.000 \mathrm{~m}^{2}\right)$ for example, to produce 200 ground apartments would culminate in 1400 apartments with a 6 - storey complex. This is workable considering the fact that there is space for parking and other facilities. This would end up taking the extra pressure that would have been exerted on land and particularly forest if horizontal construction was adopted. It is therefore realized that the extra 1200 apartments would have saved more than $120000 \mathrm{~m}^{2}$ (12ha) of land resources while still guaranteeing order in the City. This is somehow similar to what is already being realized by the MAETUR-SIC housing companies elsewhere in Cameroon. The apartments should be given out at a greatly subsidized rate so that even the urban underprivileged can afford. In addition to these 
housing strategies, there should be an Expansion of roads, the use of common transport buses and the establishment of commuters' zones or residential quarters. All of this is in order to meet up with the type of Social Lodging approach and reduce the weight of horizontal expansion.

\subsection{Forest Protection and Management}

The Forest and Wildlife regulation Law of 1994 implemented by the Ministry of Environment laid down specific tree felling modalities to be respected by forest exploiters. This is respected in protected areas and is a good idea in protecting and managing the forest. Forests provide habitat for a variety of plants and animals and perform many other important functions that affect humans. Photosynthesis is the chemical process in the leaves that uses sunlight and carbon dioxide to produce energy-supplying sugars for the tree. In this process, the foliage gives off pure oxygen for breathing. All of this will assist in the implementation of the program of REDD+.

With regards to forest management, the first step here concerns the farmers. Since subsistence farmers in these areas still cut trees for agriculture, they should be advised on how to go about things in a sustainable way by the Forestry unit of the Delegations of Forestry. Such exchanges should either be through forums like workshops or momentary visits of forest technicians. The farmers who already own established plots should then be encouraged to practice permanent farming system as in agro forestry discussed earlier.

\subsection{Forest Regeneration/Urban Forestry and Fuelwood Plantation}

The mission of regeneration of forest all over the country and Bafoussam in particular has been confided to ONADEF. This institution has however regenerated forests in some areas in the 80s but today, it is no more effectively carrying out the functions. Rather, this institution is more engaged in the sales of seedlings to those who intend to plants trees. Bafoussam town is found in the ecological zone of Western and Central Africa (ICRAF 1998). This zone supports a broad variety of multipurpose tree species. These local and exotic species would also do well in urban forestry which is a measure that has been recommended here. Another method entails the planting of woody perennials along streets or roadsides. Many other methods and rewards of urban forestry, have been viewed variously by Tyrväinen et al., (2003); Ulrich et al., (1991); Daniel, (2001a) cited in Tyrväinen (2003). In the pursuit of urban forestry in Kribi, the primordial aspects in mind are ecology, sustainability and most importantly aesthetics.

The creation of MINFOF and MINEPDED in 2005 with all the Delegations had been a recognition of the fact that forest preservation is an issue. Decree No. o3-169 of April 1982 laid down forestry regulations which had a provision for forest regeneration all over the territory. Initially forestry reforms were realized by CENADEFOR and later ONAREF (Ofice National pour le Développement de Forêts). Institutions like this should be revamped. Urban residents in the area concerned should be invited to participate in issues related decision on management of forest. Tyrvainen and Löfström (1998), hold that active participation in forest planning may increase the participants' ecological and/or silvicultural knowledge, and thus may change their preferences towards forest management options.

\subsection{Encouraging Agroforestry}

It would be very appropriate if agro-sylvo- pastoralism is practiced in and around the metropolis. The practice where trees are planted sequentially or simultaneously with crops and livestock rearing would be the most sustainable system in this area just as it has proven to be in the degraded lands of the Western Highland and the Tropical Regions as a whole as viewed variously by Fogwe 1997; ICRAF 1998; Nkwemoh 1999 \& 2011; ). The combination of trees and crops leads to an ideal situation. This practice which is referred to as agro forestry has evolved from simple planting of trees and crops to a careful selection of plants and crops according to their mutual give and take needs. This implies that the choice of the type of agro-forestry will depend on the will of farmers and agricultural extension workers in the area. All of these would obviously re-iterate the forest coverage and hence, enhance measure advocated by REDD+

\section{Conclusion}

The above research has led to the establishment of somelucid facts. Since the creation of Bafoussam, the population of the town has witnessed an exponential growth and landscape mutations. These changes have been associated with the increased need for agricultural expansion to feed the population, opening the door to land use changes with more clearings within the townscape.

It was equally realized that construction of houses by both traditional and conventional methods needs forest products in the building and roofing processes. This impact on forest vegetation has been exacerbated by the need of Fuel wood/Charcoal for domestic purposes. The degradation of forest cover has even been aggravated by the need of a wide variety of wood for woodworks/furniture especially needed in the increasing number of households. This is viewed in the lay out of specific land cover classes ranging from forest land, savanna/grassland, agiculture/farm lands/ Bare surfaces, and constructed spaces and water bodies. This situation therefore calls for an urgent reaction by the powers that be to establish a sustainable city as the ultimate way ahead.

The investigation rounds with some recommendations on the urban planning and forestry policies on forest protection and management. The measures also include forest regeneration, fuel wood plantation, agroforestry and Urban Forestry that would guarantee a true eco/sustainable city that Bafoussam is supposed to be. 


\section{References}

i. Anderson, et al. (1976):A Land Use and Land Cover Classification System for Use with Remote Sensor Data.Geological Survey. Professional Paper No. 964, U.S. Government Printing Office, Washington, D.C. p. 28.

ii. Arvind C. Pandy and M. S. Nathawat (2006):Land Use Land Cover Mapping Through Digital Image Processing of Satellite Data- A case study from Panchkula, Ambala and Yamunanagar Districts, Haryana State, India.

iii. Assako A. J. (1998) : Apport de la Télédétection et du SIG dans la Recherche des zones constructibles d'un site urbain de collines du Cameroun: Le cas du Yaoundé (Cameroun). L'espace Géographique, Tome 27, n² 2, pp. 122128.

iv. Atemfack, F.B. (2016) :L'apport de la Géomatique dans l'évaluation de l'empreinte des projets structurants sur le couvert Forestier du Cameroun dans la perspective de la REDD+: Cas du Projet du Port en Eau Profonde et du Complexe Industrialo-Portuaire. Masters Thesis University of Yaounde 1

v. Bauer M.E. Yuan F. and Sawaya K. E. (2003): Multi-Temporal Lands at Image Classification and Change Analysis of Land Cover in the twin cities (Minnesota) Metropolitan area. Second International Workshop on the Analysis of Multi-temporal Remote Sensing Images. Ispra, Italy. pp 1-8

vi. $\quad$ Baker, W.L., (1989): A Review of Models of Landscape Change, Landscape Ecology, 2:111-133.

vii. Bell, E.J., (1974). Markov analysis of land use change-Application of stochastic processes to remotely sensed data, Socio-Economic Planning Sciences, 8(6):311-316.

viii. Bopda, A. (1985) : La dynamique de l'espace urbain à Yaoundé, Reconstruction et expansion post-colonial du bâti, Thèse de Doctorat de 3ème cycle Université de Yaoundé, 312p.

ix. Bopda, A., Brummett, R., Dury, S., Elong, P., Foto, Menbohan, S., Gockoski, J., Kana, C., Kengue, J., Ngonthe, R., Nolte, C., Soua, N., Tanawa, E., Tchoundjeu, Z. and Temple, L. (2010):Urbanfarming systems in Yaounde; Building a mosaic. InPrain G., Karanja N \& Lee Smith D. 2010. African Urban Harvest. Agriculture in the cities of Cameroon.Kenya and Uganda.Chap. 3 PP. 39-60

x. Brinkman (1990):How Hungry Mouths are devouring the Planet. The Independent, Sunday, October p.58.

xi. Brown D. G, Goovaerts P., Bumlckl A., and Meng-Ylng U (2002):Stochastic Simulation of

xii. Land-Cover Change Using Geostatistics and Generalized Additive Models Photogrammetric Engineering \& Remote Sensing Vol. 68, No. 10, October 2002, pp. 1051-1061.

xiii. B.U. C (2013) : La Ville de Bafoussam: Une publication de la Communauté Urbaine de Bafoussam (B.U.C 2008 2013)

xiv. Christaller (1933):Central Place Theory - Wilkipedia Free Encyclopedia

xv. Communauté Urbaine de Bafoussam (2013). Elaboration du Plan d'Occupation Des Sols (Pos) de la Commune d'Arrondissement de BafoussamIer. Rapport Définitif

xvi. Communauté Urbaine de Bafouusam (2013):Elaboration du Plan d'Occupation Des Sols (Pos) de la Commune d'Arrondissement de Bafoussam2eme. Rapport Définitif

xvii. Communauté Urbaine de Bafouusam (2013):Elaboration du Plan d'Occupation Des Sols (Pos) de la Commune d'Arrondissement de Bafoussam 3 ${ }^{\text {eme }}$. Rapport Définitif

xviii. Coppin, P. \& Bauer, M. (1996): Digital Change Detection in Forest Ecosystems with Remote Sensing Imagery. Remote Sensing Reviews. Vol. 13. p. 207234.

xix. Daniel, et al, (2002): A comparison of Landuse and Land cover Change Detection Methods. ASPRS-ACSM Annual Conference and FIG XXII Congress pg. 2.

xx. Dimyati, etal. (1995): An Analysis of Land Use/Land Cover Change Using the Combination of MSS Lands at and Land Use Map- A case study of Yogyakarta, Indonesia, International Journal of Remote Sensing 17(5): 931 - 944 .

xxi. Ekong, E.E. (1983): Sociology of the Ibibio: A study of Sociology of Organization and Change. Calabar : Scholars Press

xxii. ERDAS, Inc. (1992): ERDAS Production Services Map State for Georgia DNR in the Monitor, Vol. 4, No 1, ERDAS, Inc, Atlanta, GA.

xxiii. Fombe, L.F \& Balgah, S.N. (2010): The Urbanization Process in Cameroon: Patterns, Implications and Prospects. Series: African Political, Economic, and Security Issues. 194p.

xxiv. GFW (2004) : L'Imagerie Satellitaire au service de L'Exploitation Forestière au Cameroun. Etat des lieux et recommandation quant à la disponibilité et l'acquisition des images. Note de synthèse. 8p.

xxv. Gleave, M.B. (1992a): Urbanisation, in M. B. Gleave (ed.) Tropical African development. Geographical Perspectives, Harlow, Longman Scientific and Technical.

xxvi. Gleave, M.B. (1992b): Urban bias and agricultural development in West Africa in West Africa in K. HOGGART (ed.) Agricultural change, environment and economy Essays in honour of WB. Morgan, London, Mansell.

xxvii. Gleave, M. B. (2001): Some issues in the urbanization of West Africa. In: C.M Lambi and E, B Eze (eds) Readings in Geography, Unique Printers, Bamenda.

xxviii. Gobster, P.H., (1999): An ecological aesthetic in forest landscape management. Landscape Journal $18(1): 54$ - 64.

xxix. Goudie, A. (1986):Human Impact on Natural Environment. The MIT press Cambridge Massachusetts, 2 nd ed

xxx. Harding, G. (1968): "The Tragedy of the Commons" Science. Volume 62, 1243- 1248

xxxi. Hastie, T., and R. Tibshirani, (1990): Generalized Additive Models, Chapman and Hall, London, United Kingdom, 335 $\mathrm{p}$

xxxii. Hauser, P. (1965): Urbanization: an overview. In: P. Hauser and L. Schnore (ed) The study of urbanization, Wiley Press, New York. 
xxxiii. https://www.ecologyandsociety.org/vol9/iss2/art1. Accessed in September 2017

xxxiv. https://www.kribicomplex.com/ Accessed in October 2017

xxxv. ICRAF (International Centre for Research in Agroforestry) (1998):Annual Report for 1997

xxxvi. Joseph Abena (2015): Inauguration du Port deKribi : Les Autorités simulant l'arrivée de Biya. La Nouvelle Expression

xxxvii. Jukka, H. and Aristide V. (1998): Land Cover/Land use classification of Urban Area; a Remote Sensing approach. International Journal on Pattern Recognition and Artificial intelligence. Vol. 12, n 4 pp. 475-489.

xxxviii. Lambi C.M. and Kah E. F. (2012): The Application of Remote Sensing in the Evaluation of Land use Dynamics in the Mount Cameroon Region. In African Journal of Social Sciences. Volume 3 Number 4. Pp 4-27

xxxix. Martin, B. (1985): Impact de l'homme sur la foret. Ecologie ou Economie? Paris pp 4-16; 111 Bibliographie extraite de Revue Forestière Française, Vol xxxvii.

xl. $\quad$ Letouzey, R. (1968): Etude phytogéographique du Cameroun. Ed Paul le Chevalier, 511p.

xli. Meyer, W.B., \& Turner, B. L., (1994): Changes in Land Use and Land Cover: A Global Perspective, Cambridge University Press, New York, N.Y., 537 p.

xlii. Mfoumban, N. G. C. (2016): Contribution de la modélisation a l'évaluation de la dynamique du trait de côte: le cas de la côte Méridional du Cameroun (1973 - 2015)

xliii. MINPAT, (2008): Répertoire des projets d'infrastructure Stratégique

xliv. MINPAT, (2012): Le projet de construction du Port en Eau Profonde de Kribi en Quelque Points

xlv. Neba Shu G. (2003): Detection Analysis of Land Cover Dynamics in Moist Tropical Rain Forest of South Cameroon. Master's Thesis. International institute of Geo-Information Science and Earth Observation, Enscheda, The Netherlands 61p.

xlvi. Ngouanet, (2007): Contribution des technologies spatiales à l'étude des risques et catastrophes naturels. Communication à l'atelier de lancement official des activités de la Fondation AZOMARC et pour le compt de la commémoration du $21 \mathrm{eme}$ anniversaire de la catastrophe du Lac Nyos, Yaoundé Chambre d' Agriculture

xlvii. Nkwemoh, C. A. (1999): The Impact of Agro-Pastoral Activities on the Physical Environment of the Mezam Ngoketunjia Area. Doctorat de 3èmeCycle Thesis, Univ. of Yaoundé 1, 282p.

xlviii. $\quad$ Nkwemoh, C. A. (2011):The Environmental Stresses of Urbanization in the Yaoundé Metropolis.Unpublished Ph. D Thesis, University of Buea. 301p.

xlix. Nkwemoh, C. A. \& Lambi, C.M. (2016): The Impact of Urbanization on Land Cover Dynamics in the Yaounde Metropolis (Cameroon). The Annals of Faculty of Arts Letters and Social Sciences, Vol 1 .No.18 pp.199-220 University of Yaounde 1. ISSN: 0379-1793 (Online)

1. Nkwemoh, C.A \& YungsiD, W. (2017): Application of Remote Sensing and GIS in the Evaluation of the Impact of the Lom Panga Hydro-Electric Power Dam Project on Vegetation Cover (Land Cover Dynamics), Cameroon. International Journal of Humanities and Social Sciences ISSN 2250-3226 Volume 7, Number 2 (2017), pp. 117-134

li. Nkwemoh, C.A, Tchindjang, M. \& Afungang, R. N. (2017): The Impact of Urbanization on the Vegetation of Yaounde, (Cameroon). International Journal of Innovative Research and Development. Vol 6 No 5 pp. 5-18 . ISSN 2278-0211 (Online)

lii. Pratt W. K. (1991): Digital Image Processing. Second Edition, Wiley, New York.

liii. Riebsame, W.E., Meyer, W.B., and Turner, B.L. II. (1994) Modeling Land-use and Cover as Part of Global Environmental Change. Climate Change. Vol. 28. p. 45.

liv. Schneider, L.C., and R.G. Pontius, (2001): Modeling land-use change in the Ipswitch watershed, Massachusetts, USA, Agriculture Ecosystems and Environment, 85:83-94.

lv. Pagiola, S., Von Ritter, K. and Bishop, J (2004): Assessing the economic value of ecosystem conservation; The World Bank, in collaboration with Nature Conservancy and IUCN, Environment Dept., number 101

lvi. Shoshany, M, et al (1994): Monitoring Temporal Vegetation Cover Changes in Mediterranean and Arid Ecosystems Using a Remote Sensing Technique: case study of the Judean Mountain and the Judean Desert. Journal of Arid Environments, 33: 9 - 21.

lvii. Silvennoinen, H., Alho, J., Kolehmainen O. \& Pukkala, T. (2001):Prediction models of landscape preference at the forest stand level. Landscape and Urban Planning 56: 11 - 20.

lviii. Silvennoinen, H., Pukkala, T. and Tahvanainen, L. (2002): Effect of Cutting on Scenic the Beauty of a Tree Stand. Scandinavian Journal of Forest Research 17: 263 - 273.

lix. Singh, A. (1989) Digital Change Detection Techniques Using Remotely Sensed Data. International Journal of Remote Sensing. Vol. 10, No. 6, p. 9891003.

lx. Soanez, S., and Simon, B. (1997): Utilisation de l'analyse diachronique dans l'étude de l'évolution du littoral oriental du delta du Rhône (France Sud Ouest) Photo interprétation numéro 1997/3-4. Pp194-154

lxi. Sterns, F, and Montag, T (1974): The urban ecosystem: a holistic approach. Dowden, Hutchinson and Ross, Stroudsburg.

lxii. Suchel, J. (1972) : Répartition des pluies et régimes pluviométrique au Cameroun. Travaux et Documents de Géographie Tropicale, 287p

lxiii. Susan, B. et al. (1992): Conserving Biological Diversity: A Strategy for Protected Areas in Asia-Pacific Region, World Bank Technical Paper No. 93

lxiv. Tarr, J. A. (1996): The search for the ultimate sink; Urban Pollution in Historical Perspectives, Akro. OH

lxv. Tahvanainen, L., Tyrväinen, L., Ihalainen, M., Vuorela, N \& Kolehmanainen, O. (2001). Forest Management \& Public Perceptions-Visual versus Verbal Information. Landscape and urban Planning, 53:53-70 
lxvi. Tonye E., Akono A. \& Ndi Nyoungui A. (2000). Le Traitement des images de Télédétection par exemple. Gordon and Beach Science Publishers, Paris 179p.

lxvii. Turner, B.L., D. Skole, S. Sanderson, G. Fischer, L. Fresco, And R. Leemans, (1995):Land-Use and Land-Cover Change Science1 Research Plan, International Geosphere-Biosphere Program and International Human Dimensions Program, Stockholm, Sweden and Geneva, Switzerland, $132 \mathrm{p}$.

lxviii. Tyrväinen, L. \& Löfström, I. (1998): Ecological and Aesthetic values in the management of urban forests. AISF-EFI international conference on Forest management in designated conservation and recreation areas 7-11 Oct 1998. Florence Italy: 295-302, University of Padua Press, Padua.

lxix. Tyrväinen, L. Nousianen, I., Silvennoinen, H. \& Tahvanainen, L. (2001):Rural Tourism in Finland: Tourists expectation of Landscape and Environment. Scandinavian Journal of Hospitality and Tourism Research. 1 (2).

lxx. Tyrväinen, L., Silvennoinen, H. and Kolehmainen 0. (2003): Ecological and Aesthetic values in urban forest management. In Urban Forestry and Urban Greening 1: 135 - 149.

lxxi. U.S. Geological Survey, (1999): The Landsat Satellite System Link, USGS on the World WideWeb. URL: http://landsat7.usgs.gov/landsat_sat.html.

lxxii. Vennetier, P.(1973): Problème de croissance urbaine dans le monde tropical. CEGET CNRS, 152p.

lxxiii. Vennetier, P. (1989): La périurbanisation dans les pays tropicaux. Espaces Tropicaux No.1 CEGET, 384p.

lxxiv. Vennetier, P (1991): Urbanisation et développement dans les pays Tropicaux. Espace Tropicaux, No.4, CEGET, 198p.

lxxv. Verger, F. (1996): La télédétection des domaines Littoraux. In Bonn F. (Ed) Précis de télédétection. Vol 2. Application Thématique. Presse de l'Université de Québec (AUPELF), Saint - Foy, pp. 323 - 343

lxxvi. Wilkie, D.S., and Finn, J.T. 1996. Remote Sensing Imagery for Natural Resources Monitoring. Columbia University Press, New York. p. 295.

lxxvii. Youana, J. (1983): Les quartiers spontanés péricentraux de Yaoundé. Une Contribution à l'étude de l'habitat du plus grand nombre. Thèse de Doctorat du 3ème cycle, Université de Yaoundé, 324p.

lxxviii. Zoning, A.,\& Kuete M. (1985): L'équilibre écologique du littoral Camerounais. Données géographique du problème. Xeme Colloque SEPANRIT CEGET. Cayenne: 229 - 237. 